\title{
Relationship Between Nutritional Status and the Incidence of ARI Among Under-Five Children (13-59 Months) in the Work Area Community Health Center Unit
}

\author{
$1^{\text {st }}$ Ira Faridasari \\ Nursing Departement \\ Sekolah Tinggi Ilmu Kesehatan \\ Cirebon \\ Cirebon, Indonesia \\ Ira_faridasari@yahoo.com \\ $4^{\text {th }}$ Ela Rohaeni \\ Nursing Departement \\ Sekolah Tinggi Ilmu Kesehatan \\ Cirebon \\ Cirebon, Indonesia
}

\author{
$2^{\text {nd }}$ Lin Herlina \\ Nursing Departement \\ Sekolah Tinggi Ilmu Kesehatan \\ Cirebon \\ Cirebon, Indonesia \\ $5^{\text {th }}$ Rifatun Nisa \\ Nursing Departement \\ Sekolah Tinggi Ilmu Kesehatan \\ Cirebon \\ Cirebon, Indonesia
}

\author{
$3^{\text {rd }}$ Iis \\ Nursing Departement \\ Sekolah Tinggi Ilmu Kesehatan \\ Cirebon \\ Cirebon, Indonesia
}

\author{
$6^{\text {th }}$ Maria Ulfah \\ Nursing Departement \\ Sekolah Tinggi Ilmu Kesehatan \\ Cirebon \\ Cirebon, Indonesia
}

\begin{abstract}
The health development goals as stated in the National Health System are efforts to implement health carried out by the Indonesian people in order to obtain the ability to live a healthy life for each community in order to realize a high health degree. The better the nutritional status of children, especially under-five children, the better the immune system so that the children are not susceptible to infectious diseases such as ARI. In fact, there are bout 100 million people of Indonesia who are declared malnourished. This study aims to determine whether there is a relationship between nutritional status and the incidence of ARI among under-five children (13 - 59 months) at Lelea CHC Unit. The study type used was descriptive correlational (correlational study). Correlational descriptive study (correlational study) is a research/study on the relationship between two variables in a situation or using Cross Sectional approach, namely the collection of data regarding the independent variable (nutritional status) and the dependent variable (ARI disease) as study objects, the data are observed, examined and measured in the same time or in a certain period. From the results of data processing using the Chi-Square test it was obtained a lower P-count $(0.01)$ which meant that there was a significant relationship between nutritional status and the incidence of ARI among under-five children (13 - 59 months) in the work area. Based on the results of this study, it can be concluded that there was a relationship between nutritional status and the incidence of ARI among under-five children (13 - 59 months). It is recommended that patients with ARI should improve their nutritional status, so that they are not easily infected by ARI. The assessment of nutritional status is performed regularly using height measurement and weight check in each month.
\end{abstract}

Keywords-Nutritional, ARI, Children

\section{INTRODUCTION}

The health development goals that have been listed in the National Health System are the efforts to implement health carried out by the Indonesian people in order to obtain the ability to live a healthy life for each community in order to realize an optimal degree of public health. It is said that the increase in the degree of public health is influenced by several factors namely the environment, health services, treatment and congenital. Healthy life is a right that is owned by every human being in this world, but it takes various ways to get it [1].

Increased incidence and severity of acute lower respiratory tract infection (ALRI) are variably associated with malnutrition [2]. Increased incidence and severity of acute lower respiratory tract infection (ARI) Cough accompanied by short/rapid breath and chest problem within 2 weeks was considered as the symptoms of ARI [3].

Indonesia, which is one of the developing countries has the incidence of acute respiratory infections (ARI) which, always ranks first of the cause of death among infants and under-five children. In addition, ARI is often in the list of 10 most diseases in hospitals or health centers. Mortality survey conducted by ARI Sub Directorate in 2010 placed ARI/Pneumonia as the main cause of infant death in Indonesia with a percentage of $22.30 \%$ of all under-five deaths [4]. Previous research conducted by Elyana (2013) the title is Relationship between ISPA Frequency and Toddler Nutrition Status, shows the results that nutritional status is related to ARI frequency $(p<0.05)$ $[5]$.

In another study conducted by Almiral (2015), The Correlation Between Nutritional Status With Acute Respiratory Infection (ARI) Incident in Children Under 
Five in The Working Area of Puskesmas Siantan Hilir show the result there is a relation between nutrition status and acute respiratory infections (ARI) to children under five in the working area of Puskesmas Siantan Hilir [6].

Based on the results of a preliminary study that was conducted on November 2, - November 30, 2015, the data obtained during the period January 2015- March 2015 at Lelea CHC Unit, Indramayu District showed that ARI ranked the first. It was recorded that out of 150 under-five children there were 55 children experienced ARI and most of them were under-five children with underweight nutritional status [7]. Based on the background described above, the writer considers that a study needs to be conducted with the title of "Relationship between Nutritional Status and the Incidence of ARI among Underfive Children (13- 59 Months) at CHC Unit".

\section{METHODS}

This study used a descriptive analytic design with cross sectional approach, wherein independent and dependent A. Univariate Analysis

TABLE.1 DISTRIBUTION OF NUTRITIONAL STATUS AMONG UNDER-FIVE CHILDREN (13-59 MONTHS).

\begin{tabular}{|c|c|c|c|c|}
\hline $\begin{array}{c}\text { Number of Under-five Children (13- } \\
59 \text { months) }\end{array}$ & Severely underweight & Underweight & Normal & \\
\cline { 2 - 5 } & 1 & 58 & 66 & 100 \\
\hline 125 CHILDREN & & & & \\
\hline
\end{tabular}

Based on table 1 above, it was known that of all under-five children (13-59 months) more than half of respondents $(53 \%)$ had a normal nutritional status.

TABLE.2 DISTRIBUTION OF CHILDREN WITH ARI AMONG UNDER-FIVE CHILDREN (13-59 MONTHS)

\begin{tabular}{|c|c|c|c|c|}
\hline \multirow{2}{*}{$\begin{array}{c}\text { Number of Under-five Children (13-59 } \\
\text { months) }\end{array}$} & \multicolumn{3}{|c|}{ ARI } & \multirow{2}{*}{ (\%) } \\
\cline { 2 - 5 } & Severe Pneumonia & Pneumonia & Non-pneumonic cough & \\
\hline 125 CHILDREN & 3 & 65 & 57 & 100 \\
\hline
\end{tabular}

Based on Table 2 above it was shown of 125 underfive children (13 -59 months) studied as many as 3 children

$(2.4 \%)$ had severe pneumonia, 65 people $(52 \%)$ had pneumonia and as many as 57 children $(46 \%)$ had NonPneumonic Cough.

\section{B. Bivariate Analysis}

TABLE.3 CROSS TABLE OF THE RELATIONSHIP BETWEEN NUTRITIONAL STATUS AND THE INCIDENCE OF ARI AMONG UNDERFIVE CHILDREN (13-59 MONTHS)

\begin{tabular}{|l|l|l|l|l|l|l|}
\hline \multirow{2}{*}{ No } & Nutritional Status & \multicolumn{2}{l|}{ ARI } & \multicolumn{2}{l|}{} \\
\cline { 3 - 8 } & & Severe Pneumonia & Pneumonia & Non-pneumonic cough & TOTAL & $(\%)$ \\
\hline 1 & Normal & 1 & 24 & 41 & 66 & 53 \\
\hline 2 & & & & & & \\
\hline 3 & Underweight & 2 & 41 & 15 & 58 & 46 \\
\hline
\end{tabular}

Based on the study and table 3 above, it can be explained that of 125 respondents with normal nutritional status 1 respondent $(0.8 \%)$ experiencaed severe pneumonia, 24 respondents $(19.2 \%)$ experienced pneumonia and 41 respondents (32.8) expereinced non-pneumonic cough.

Furthermore, regarding underweight nutritional status, 2 respondents $(1.6 \%)$ experienced severe pneumonia, 41 respondents $(32.8 \%)$ experienced pneumonia and 15 variables were assessed at the same time. The study was conducted among under-five children (13 - 59 months) who were suffering from coughs, colds, heat accompanied by

\section{RESULTS}

This study was conducted on March 1 to March 12, 2016. The samples in this study were taken using namely under-five children (13 - 59 months) who were suffering from cough, runny nose, fever accompanied by apid breath/shortness of breath.

The results of the study are presented in a row namely data on characteristics, univariate analysis and bivariate analysis as follows. 
very significant relationship between nutritional status and the level of ARI among under-five children (13 - 59 months) in the work area of Lelea CHC Unit.

\section{DISCUSSION}

Based on the results of the study, researchers attempeted to present discussions in order to answer the formulation of problems related to the relationship between nutritional status and the level of ARI among infants (13 - 59 months) in the work area of the Lelea CHC Unit. The discussion presented here is intended to compare the theory and the study findings.

\section{A. Nutritional Status}

The results of the study and table 1 above showed that of the total sample of 125 under-five children (13 - 59 months) 58 children (46\%) had underweight nutritional status and 66 children (53\%) had normal nutritional status and 1 children had severely underweight nutritional status or edema.

Nutritional status is a measure of success in meeting the nutrition needs for children as indicated by body weight and height as a result of balance between needs and nutrient intake. Normal nutritional status is a hope for parents. The better the nutritional status of children, especially under-five children, the better the immune system so that they are not easily affected by infectious diseases such as ARI. Nutrition problems in every life cycle begin from fetus in the uterus, infants, children and the elderly. Malnutrition experienced by the community is due to a lack of micronutrients namely iron, vitamin A and iodine consumed. Undernutrition and malnutrition result in growth disorder and the sufferer is susceptible to infectious diseases such as ARI, Diarrhea, TB, and malaria (4). Child malnutrition can manifest itself in several ways. It is commonly assessed trough measurement of a child's weight and height, as well as trough biochemical and clinical assessment [8]. Acute respiratory infections (ARI) are a leading cause of morbidity and mortality in under-five children worldwide. About 6.6 million children less than 5 years of age die every year in the world; $95 \%$ of them in low-income countries and one third of the total deaths is due to ARI.

\section{B. ARI}

Based on the study results and table 2 above, it was shown that of the total sample of 125 under-five children (13 - 59 months) as many as 3 chidlren (2\%) experienced severe pneumonia, as many as 65 children (52\%) experienced pneumonia and as many as 57 chidlren (46\%) experienced non-pneumonic cough.

Acute Respiratory Infection (ARI) is an upper and lower respiratory tract infection that starts from the nostrils to the lungs characterized by coughing, colds, fever, earaches and difficulty of breath. Episodes of cough, runny nose, fever among infants in Indonesia are estimated at 3 to 6 times per year. This means that in average under-five children experience cough, runny nose, and fever 3-6 times a year which can cause death.

Under nutrition is a concetrated problem of low national priority. $80 \%$ of the world's undernourished children are living in just 20 countries. [9] Better nutrition translates into a stronger and healthier population with greater opportunities of breaking the cycle of poverty and achieving better quality of life [10].

Based on the research and table 3 above, it can be explained that of 66 respondents with normal nutritional status, 1 respondent $(0.8 \%)$ experienced severe pneumonia, 24 respondents (19.2\%) experienced pneumonia and 41 respondents (32.8) experienced non-pneumonic cough

Of 58 respondents with underweight nutritional status, 2 respondents $(1.6 \%)$ experienced severe pneumonia, 41 respondents $(32.8 \%)$ experienced pneumonia and $15(12 \%)$ respondents experienced non-pneumonic cough.

For severely underweight nutritional status of 1 respondent $(0.8 \%)$ suffering from Non-pneumonic cough. Child malnutrition isalsothe most pressing problem of the world, damaging both children andthe nations. Significant proportion of deaths of young 12 childrenWorldwide is due to malnutrition and efforts to reduce malnutrition should be a policy priority [11].

The better the nutritional status of children, especially under-five children, the better the immune system so that the children are not susceptible to infectious diseases such as ARI. Nutritional status is a measure of success in meeting the nutrition needs for children as indicated by body weight and height as a result of balance between needs and nutrient intake. The optimal balance between the need and nutrient input can be obtained from food and drinks consumed by children since the early age, good nutrition is guided by a balanced nutrition that is the appropriate amount of nutrients in accordance with the body requirements obtained from carbohydrates, proteins, fats and minerals.

The problem that occurs in Indonesia as a developing country is that around 100 million people in Indonesia are declared nutritionally deficient, in average under-five children experience 3-4 times of ARI incidnce, one of which is influenced by underweight nutritional status.

\section{Conclusions}

The results of data processing using the Chi-Square statistical test showed that the $\mathrm{P}$ value obtained was 0.01 while this study used $a$ value of 0.05 . Thus the $\mathrm{P}$ value was lower than the $a$ value, then Ho was rejected and Ha was accepted. After analyzing the data, it turned out there was a very significant relationship between nutritional status and the level of ARI among under-five children (13 - 59 months) in the work area of Lelea CHC Unit.

\section{REFERENCES}

[1] Depkes Ri, Penyakit ISPA. 2007.

[2] R. Bhat Yellanthoor and V. Ramdas, "Frequency and intensive care related risk factors of pneumothorax in ventilated neonates," Pulm. Med., vol. 2014, no. May 2006, 2014.

[3] "Unit of Health Promotion Research, University of Southern Denmark, Esbjerg, Denmark," 2015.

[4] Manajemen Terpadu Balita Sakit.modul 1,2,3,4,5,6 dan 7. 2009.

[5] Mei Elyana, "Relationship between ISPA Frequency and Toddler Nutrition Status," J. Nutr. Heal., vol. Vol 1, No, 2013.

[6] Raina Ulva Almira, "The Correlation Between Nutritional Status With Acute Respiratory Infection (ARI) Incident in Children Under Five in The Working Area of Puskesmas Siantan Hilir," Proners, vol. Proners Vo, 2015. 
[7] Dinkes, "DinKes Provinsi Jawa Barat. Profil," 2008. .

[8] UNICEF, "Improving Child Nutrition:The achievable imperative for progress,New York: United Nations," 2013. .

[9] P. Pradmore, Addressing the Underlying and Basic Causes of Child Undernutrition in Developing Countries:What Works and Why?, s.l.: s.n. 2009.

[10] C. . Azzari, Child Undernutrition in Mozambique, s.l.: s.n. 2011.

[11] P. Wijesinghe.D.G.N.G, "Nutritional Status of under 5 Year-Old Children and its Relationshipwith Maternal Nutrition Knowledge in Weeraketiya DS division ofSri Lanka. Tropical Agricultural Research,” vol. Vol. 21(4), 2010. 